\title{
Editorial of special issue 2016 Portsmouth - Fordham conference on Banking and Finance
}

\author{
The Guest Editors \\ Ioannis Chatziantoniou, University of Portsmouth, UK \\ Iftekhar Hasan, Fordham University, USA \\ Fotios Pasiouras, Montpellier Business School, France
}

In September 2016, the Portsmouth Business School (University of Portsmouth, UK) and the Center for Research in Contemporary Finance (Fordham University, USA) organized an international conference on Banking and Finance. The program included nearly 200 presentations, and plenary speeches by prominent scholars. After a rigorous double-blind review process, eight high quality papers were accepted for inclusion in this special issue of Financial Markets, Institutions \& Instruments. We discuss these studies briefly below. The first three studies examine various aspects of the mortgage market. The fourth study also focuses on tangible asset backed loans, although the application of the proposed framework is not limited to mortgages. The fifth and sixth study deal with information asymmetry in stock markets. The last two papers focus on bank risk.

Deku, Kara and Marques-Ibanez consider the role of trustees in securitization pricing and whether investors relied on trustees to mitigate mortgage backed security (MBS) risks. Using a sample of European MBS issuances between 1999 and 2007, they find that engaging reputable trustees led to lower spreads during the credit boom period prior to the 2007-2009 financial crisis. They also conclude that the reputation of trustees was regarded as a critical yardstick, as risk assessment became more difficult. Finally, they show that while investors experienced extensive losses during the crisis, they did not exclusively rely on credit ratings.

Antinolfi and Brunetti examine the relationship between the volatility of US economic activity and MBS markets between 1974 and 2011. Using quarterly observations, they construct various measures of volatility for the growth rates of real GDP, consumption, housing consumption, residential investment, and investment in single housing. Subsequently, they examine the empirical relation between real and financial variables using a linear autoregressive model and a non-linear Markov switching model. Their results show a negative relationship between the growth of mortgagebacked securities and the volatility of real activity in the first part of the sample, between the mid -1970s and 2000; however, in the second part of the sample the relationship is to some extent reversed, with volatility in real economic growth being positively related to changes in the MBS market volume.

Delis, Hasan and Tsoumas use a rich dataset on mortgage applications from the HMDA for the period 1992-2012 to test the hypothesis that the income elasticity of mortgage loan demand increased in the period 2002-2006. Using loan-demand equations they find that the income elasticity of mortgage loan demand not only did not rise for the middle class before the eruption of the subprime crisis, but in fact it considerably fell for the mid- and lower-middle class income groups during that period. As the authors highlight, the decreases are quite large: in 1997 a $10 \%$ increase in the income of the applicants belonging in either of the mid- or lower-middle groups increases the amount of loan demanded by approximately $6 \%$; in 2007 the same increase raises the amount of loan demanded by only $3 \%$. The authors interpret their findings as evidence that increases in the house prices during the pre-crisis period were not matched by increases in income of middle-class individuals to purchase a given additional increment of housing.

Wojakowski, Ebrahim, Jaafar and Osman Salleh propose a theoretical model for structuring collateralized loans free of the endemic risk of default. The authors employ the pragmatic approach of a margin loan in the configuring of collateralized debt to yield a quasi-default-free facility and link it to the current Basel III regulatory framework. Their findings support the view that a default-prone collateralized loan has a receding economic efficiency with heightened agency cost accruing to the risk of default. The authors conclude by discussing various policy implications of this work. 
Boubaker, Gounopoulos and Rjiba examine the effect of annual report textual complexity on firms' stock liquidity. Their work falls within a growing strand of the literature that employs techniques from computational linguistics to assess the quality or enhance the use of firm financial disclosure. Using a sample of 507 French non-financial firms included in the CAC All Shares Index from 2002 to 2013 they find that less readable filings are associated with lower stock liquidity. They also reveal that difficult-to-read annual reports hinder investors' ability to process and analyze information contained in annual reports, reducing their willingness to trade which decreases stock liquidity.

Küllü, Dyer, Yilmaz and Sharma examine the relationship between business group affiliation and stock price informativeness in an emerging market setting. They focus on Turkey which is a high-growth, but less studied, emerging market setting where business groups (holdings) play a dominant role in the economy. Their results show that the amount of firm-specific information capitalized into stock prices tends to be lower when the firm is group-affiliated, indirectly owned, and affiliated group has a group bank. They also reveal a non-linear relationship between group affiliation and synchronicity.

Mamatzakis, Matousek and Vu examine the impact of problem loans on the productivity growth of Japanese banks. Using a new data set of bankrupt and restructured loans, which are disaggregated from "risk-monitored loans" disclosed subject to the Japanese Banking Law, the authors propose a novel and flexible productivity growth decomposition. They also investigate the convergence - catching up effect - among Japanese banks and geographic regions by using club convergence analysis. They main results can be summarized as follows: (i) productivity growth in Japanese commercial banks is impaired by the impact of bankrupt loans, (ii) the destructive effect of these loans varies over time, appearing to capture events such as government interventions, the global financial crisis, and the Tohoku tsunami/earthquake, (iii) there is divergence in productivity growth across regions over time.

Degl'Innocenti, Fiordelisi, Girardone and Radić examine the relationship between competition and risk-taking in investment banking. Therefore, the key contribution of their work is that it departs from the traditional commercial banking literature, and it extends our knowledge by focusing on a market segment that played a critical role in generating and spreading the global financial crisis. Another interesting aspect of their work is that they distinguish between boutique investment banks and full-service investment banks. Using a sample of banks operating in seven developed economies over the period 1997-2014 and a panel VAR model, they conclude that higher competition (low market power) is associated with higher risk exposure for both types of banks in terms of increase in earnings-at-risk or revenue volatility. However, they also find a positive relationship between market power and market risk. Finally, their results show that smaller and more specialized boutique investment banks are less likely to be affected by changes in competition, while bigger and full-service banks appear to increase their risk-exposure as competition increases as well.

In closing, we would like to thank the Editor of FMII, Professor Anthony Saunders, for giving us the opportunity to edit this special issue. We are also grateful to all the referees who reviewed the submitted papers. Last but not least, we would like to thank all the conference participants for various comments that improved the submitted papers, and all the authors that submitted their work for publication consideration in the present special issue. We hope that you will enjoy reading all the selected papers. 